\title{
Purification and properties of staphylocoagulase
}

Citation for published version (APA):

Bas, B. M., Muller, A. D., \& Hemker, H. C. (1974). Purification and properties of staphylocoagulase. Biochimica et biophysica acta. Protein structure, 379(1), 164-171. https://doi.org/10.1016/00052795(75)90018-5

Document status and date:

Published: 01/01/1974

DOI:

10.1016/0005-2795(75)90018-5

Document Version:

Other version

\section{Please check the document version of this publication:}

- A submitted manuscript is the version of the article upon submission and before peer-review. There can be important differences between the submitted version and the official published version of record.

People interested in the research are advised to contact the author for the final version of the publication, or visit the DOI to the publisher's website.

- The final author version and the galley proof are versions of the publication after peer review.

- The final published version features the final layout of the paper including the volume, issue and page numbers.

Link to publication

\footnotetext{
General rights rights.

- You may freely distribute the URL identifying the publication in the public portal. please follow below link for the End User Agreement:

www.umlib.nl/taverne-license

Take down policy

If you believe that this document breaches copyright please contact us at:

repository@maastrichtuniversity.nl

providing details and we will investigate your claim.
}

Copyright and moral rights for the publications made accessible in the public portal are retained by the authors and/or other copyright owners and it is a condition of accessing publications that users recognise and abide by the legal requirements associated with these

- Users may download and print one copy of any publication from the public portal for the purpose of private study or research.

- You may not further distribute the material or use it for any profit-making activity or commercial gain

If the publication is distributed under the terms of Article $25 \mathrm{fa}$ of the Dutch Copyright Act, indicated by the "Taverne" license above, 
Reprinted from

Biochimica et Biophysica Acta, 379 (1974) 164-171

(C) Elsevier Scientific Publishing Company, Amsterdam - Printed in The Netherlands

BBA 36912

\title{
PURIFICATION AND PROPERTIES OF STAPHYLOCOAGULASE
}

\author{
B. M. BAS, A. D. MULLER and H. C. HEMKER*
}

Laboratory of Cardiovascular and Blood Coagulation Biochemistry, Department of Internal Medicine. University Medical Centre, Leiden (The Netherlands)

(Received July 2nd, 1974)

\section{SUMMARY}

Staphylocoagulase, an exoprotein of coagulase-positive Staphylococci, has been purified to a state in which only trace amounts of contaminating proteins are detectable. Aspartic acid was found as a single $\mathrm{N}$-terminal amino acid in this preparation. The molecular weight is 61000 ; the isoelectric point lies at $\mathrm{pH} 4.53$. The amino acid composition was determined.

\section{INTRODUCTION}

Staphylocoagulase is a protein secreted by certain strains of Staphylococcus aureus. Upon the interaction of this protein with prothrombin, a thrombin-like activity arises. Several authors have reported on the purification of staphylocoagulase [1-9] but none of them describes a procedure yielding a product of sufficient purity to permit the type of experiments intended to investigate the mode of interaction of staphylocoagulase and prothrombin [13].

\section{MATERIALS AND METHODS}

Unless stated otherwise, all chemicals were obtained from Merck and were of analytic grade. Brain-heart infusion was obtained from Difco. Sephadex G-100 and DEAE-Sephadex A-100 were from Pharmacia Fine Chemicals. Polyacrylamide gels for chromatography were obtained from Biorad. The DEAE-cellulose used for step 2 was Batch D 8382 from Sigma. For the final chromatography, microgranular DEAE cellulose DE 32 from Whatman was used; for ultrafiltration, a Diaflow apparatus with membrane XM-50. Rabbit plasma was obtained from healthy rabbits by cardiac puncture. The blood was collected in $1 / 10$ volume $0.01 \mathrm{M}$ sodium oxalate and was centrifuged twice $(10 \mathrm{~min}$ at $4000 \times g$ and $20 \mathrm{~min}$ at $20000 \times \mathrm{g})$ to obtain plateletpoor plasma. Bovine fibrinogen was a freeze-dried preparation obtained from Behringwerke A.G.

* To whom all correspondence should be addressed at the Medical Faculty Maastricht, Tongersestraat 53, Maastricht, The Netherlands. 


\section{Protein determination}

Protein was determined according to Lowry et al. [10] with crystalline bovine serum albumin as standard. For rapid protein measurement, the biuret method [11] was used. $E_{280}$ was measured with column fractions.

\section{Lipid analysis}

Phospholipids were extracted from the samples according to Bligh and Dyer [12]. The chloroform phase was dried under an air stream and digested with conc. $\mathrm{H}_{2} \mathrm{SO}_{4}$ and $72 \%$ perchloric acid. The phosphorus content was then measured according to Chen et al. [14]. Total phospholipids were calculated from the phosphorus content, as indicated by Wagener [15]. Total lipids were extracted from the samples by the procedure of Bligh and Dyer [12] and determined by a gravimetric procedure [16].

Amino acid analysis was carried out on a Beckman type Unichrom amino acid analyser, using a Beckman PA 27 column and the Beckman calibration mixture no. 312220 . The procedure of ref. 17 was followed. Losses during hydrolysis were compensated for by extrapolation to zero hydrolysis time.

\section{Determination of $N$-terminal amino acids}

The $\mathrm{N}$-terminal amino acids of the purified protein were determined by the dansyl chloride method of Gray [18] and the dansyl amino acids were identified on $5 \times 5 \mathrm{~cm}$ polyamide sheets by using the system of Woods and Wang [19] with the modification described by Croft [20].

For the estimation of molecular weights, sodium dodecylsulphate-polyacrylamide gel electrophoresis was performed according to Weber and Osborn [21]. The samples (volume $0.05-0.10 \mathrm{ml})$ were mixed with tracking dye $(5 \mu 10.05 \%(\mathrm{w} / \mathrm{v})$ Bromphenol Blue) after which sodium dodecylsulphate was added $(10 \% \mathrm{w} / \mathrm{v}, 5 \mu \mathrm{l})$. When necessary, $\beta$-mercaptoethanol $(5 \mu \mathrm{l})$ was added and the mixture was then heated $\left(100{ }^{\circ} \mathrm{C}, 2 \mathrm{~min}\right)$ before electrophoresis. The gels $(8 \% \mathrm{w} / \mathrm{v}$ acrylamide and $0.27 \% \mathrm{w} / \mathrm{v}$ methylene bisacrylamide) were polymerized and run at a constant current of $8 \mathrm{~mA} / \mathrm{gel}$ until the tracking dye had moved at least $5 \mathrm{~cm}$. The gels were stained in Coomassie Brilliant Blue and destained by soaking in $7.5 \%(\mathrm{v} / \mathrm{v})$ acetic acid-5\% (v/v) methanol.

Analytical polyacrylamide gel electrophoresis was carried out in an analogous way with omission of the sodium dodecylsulphate.

\section{Gel filtration}

Molecular weight determinations were performed with Biogel P-100 according to Whitaker in a $1.5 \times 100 \mathrm{~cm}$ glass column [22]. The flow rate was kept constant at $12 \mathrm{ml} / \mathrm{h}$ by pumping. Fractions $(3 \mathrm{ml})$ were collected and the absorbance was read at $280 \mathrm{~nm}$.

\section{Isoelectric focusing}

Isoelectric focusing was carried out in a sucrose gradient in $1 \% \mathrm{w} / \mathrm{v}$ Ampholine buffers in the $\mathrm{pH}$ range of 3-6 as described by Haglund [23]. To prevent precipitation at the isoelectric point of the protein, focusing was carried out in the presence of 7 $\mathrm{mM}$ urea [24] and BRIJ-35 (polyoxyethylene dodecylether) a non-ionic detergent $[25,26]$. 
Determination of staphylocoagulase

Essentially, the method of Soulier was followed [7]. A glass tube in a water bath was provided with: $0.1 \mathrm{ml}$ rabbit plasma diluted $1: 20,0.1 \mathrm{ml}$ bovine fibrinogen $4 \mathrm{mg} /$ $\mathrm{ml}, 0.2 \mathrm{ml}$ veronal acetate buffer $(\mathrm{pH} 7.35)$ and a $0.1-\mathrm{ml}$ sample containing staphylocoagulase.

At the addition of the sample, a stopwatch was started. The moment of coagulation was assessed by hand with a $5 \times 30 \mathrm{~mm}$ stainless steel hook, the stopwatch being stopped at that moment. When the activity was to be assessed in slices of a polyacrylamide gel, each 2-mm slice was fragmented in $0.2 \mathrm{ml}$ buffer after which $0.2 \mathrm{ml}$ of a mixture of equal parts of diluted rabbit plasma and bovine fibrinogen solution were added. One crude preparation of staphylocoagulase (obtained after the acid precipitation step to be described below) was considered to contain 100 arbitrary units per ml.

Coagulation times obtained with dilutions of this preparation were used to construct a reference curve. This curve was a hyperbola, since the plot of coagulation times against the inverse of the concentration of staphylocoagulase was a straight line. The standard preparation was frozen at $-70{ }^{\circ} \mathrm{C}$ in small portions and remained stable for more than two years.

This approach is preferable to basing the definition of a unit on a coagulation time [7] because variations in rabbit plasma or fibrinogen will not influence the unit defined.

\section{PROCEDURE}

A strain of Staphylococcus aureus (originally strain 104 of Tager [7]) kindly provided by Professor Soulier was stored at $-70^{\circ} \mathrm{C}$ in broth. Every two months a fresh broth was inoculated and stored after $24 \mathrm{~h}$ of culture growth. For mass culture, the broth was used to inoculate $1 \%$ glucose-blood agar. After $24 \mathrm{~h}$ at $37{ }^{\circ} \mathrm{C}$ three tubes of blood agar were mixed into $100 \mathrm{ml}$ brain-heart infusion (Difco). This infusion was kept at $37^{\circ} \mathrm{C}$ for $48-72 \mathrm{~h}$ in 1-litre Roux flasks, after which the material from 30 flasks was pooled and centrifuged for $30 \mathrm{~min}$ at $7000 \times \mathrm{g}$. The supernatant was then filtered through a G-5 glass filter.

The material was brought to $\mathrm{pH} 4.5$ with $3 \mathrm{M} \mathrm{HCl}$ and left for $18 \mathrm{~h}$ at $0{ }^{\circ} \mathrm{C}$. The precipitate was collected by centrifugation $\left(20 \mathrm{~min}\right.$ at $\left.5000 \times \mathrm{g}, 4{ }^{\circ} \mathrm{C}\right)$ and washed twice in $1 / 10$ vol. $0.15 \mathrm{M}$ sodium acetate ( $\mathrm{pH}$ 3.8) before being dissolved in $1 / 20$ vol. $0.05 \mathrm{M}$ Tris- $\mathrm{HCl}$ ( $\mathrm{pH} 7.35$ ) containing $0.10 \mathrm{M} \mathrm{NaCl}$. Then one half volume of DEAE-cellulose slurry $(75 \mathrm{mg} / \mathrm{ml}$ in $0.015 \mathrm{M}$ Tris- $\mathrm{HCl}, \mathrm{pH} 7.35)$ was added. After stirring for $10 \mathrm{~min}$ at room temperature, the cellulose was separated on a G-2 sintered glass filter and washed repeatedly with $20 \mathrm{ml}$ of Tris- $\mathrm{HCl} 0.05 \mathrm{M}$ (pH 7.35) containing $0.15 \mathrm{M} \mathrm{NaCl}$. Washing was stopped when coagulation times longer than $60 \mathrm{~s}$ were found in the eluting fluid (after 9-12 washings). The pooled washing fluids were concentrated by ultrafiltration using a Diaflow apparatus with a XM-50 membrane.

A $100-\mathrm{ml}$ aliquot of the preparation $\left(0^{\circ} \mathrm{C}\right)$ was added slowly to a mixture of $100 \mathrm{ml}$ ethanol and $100 \mathrm{ml}$ diethylether at $-10^{\circ} \mathrm{C}$. After $30 \mathrm{~min}$ of incubation $2.5 \mathrm{ml}$ water was added. The resulting ethanol-water layer (about $240 \mathrm{ml}$ ) was separated from the ether layer and $160 \mathrm{ml}$ of a saturated solution of ammonium sulphate was added to it. This again separated into two phases. The lower one contained the staphylocoagulase in the form of a fine precipitate which was collected by centrifugation (10 


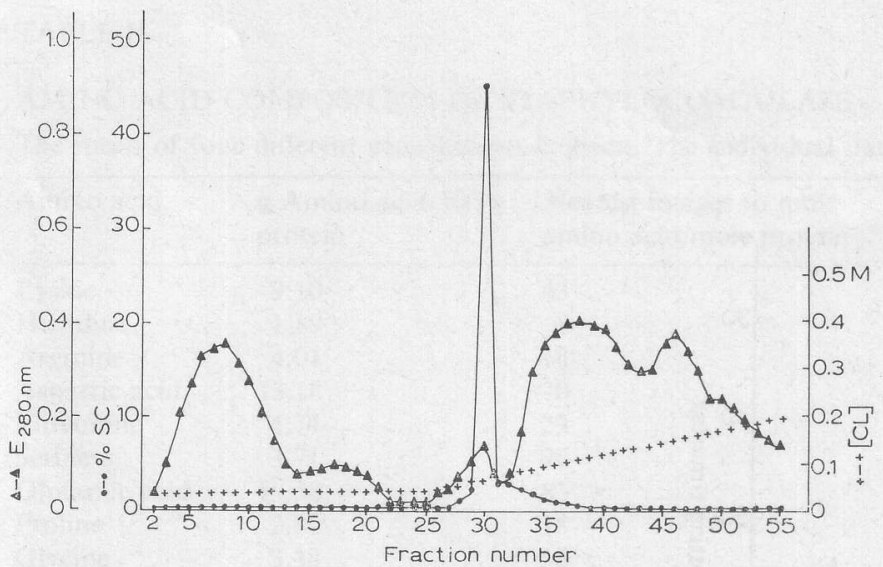

Fig. 1. DEAE-cellulose chromatography of staphylocoagulase. $\mathbf{A}$, adsorbance at $280 \mathrm{~nm}$; - activity of staphylocoagulase in $\%$ (SC scale); +++ , concentration of chloride ions (CL scale).

min at $-10^{\circ} \mathrm{C}, 2000 \times g$ ) and suspended in $100 \mathrm{ml} n$-pentane at $-10^{\circ} \mathrm{C}$, again centrifuged and freeze-dried. The dry powder was repeatedly extracted by $20 \mathrm{~min}$ of stirring at room temperature with $20 \mathrm{ml}$ Tris buffer ( $\mathrm{pH} 7.35) 0.15 \mathrm{M} \mathrm{NaCl}$, until the coagulation time of the supernatant exceeded $60 \mathrm{~s}$ (2-4 times). Lipid extraction with alcoholether and pentane in this system was absolutely necessary for the following chromatography to be successful. Before extraction the material contained $43 \mu \mathrm{g}$ phospholipids and $628 \mu \mathrm{g}$ triglyceride per mg protein. After extraction no phospholipid and less than $20 \mu \mathrm{g}$ triglyceride was detected. The preparation was diluted five times with a $0.02 \mathrm{M}$ borate buffer ( $\mathrm{pH} 5.5$ ) and applied to a $2.5 \times 10 \mathrm{~cm}$ column of DEAE-cellulose equilibrated with the same buffer containing $0.03 \mathrm{M} \mathrm{NaCl}$. When $280 \mathrm{~nm}$-adsorbing material no longer eluted. a linear gradient of $0.03-0.25 \mathrm{M} \mathrm{NaCl}$ in the same buffer was applied $(2 \times 100 \mathrm{ml})$. The staphylocoagulase elutes as a sharp peak shortly afterwards, at about $0.07 \mathrm{M} \mathrm{NaCl}$ (Fig. 1). The course of the procedure is summarized in Table I.

Fig. 2 shows a scan of a polyacrylamide-electrophoresis pattern of the final product. In a parallel unstained run the activity was measured. The maximal activity

\section{TABLE I}

\section{PURIFICATION OF STAPHYLOCOAGULASE}

Values represent the means of 10 purification procedures. The highest specific activity observed was 41800 units/mg, the lowest 35200 .

\begin{tabular}{lcccccr}
\hline Procedure & $\begin{array}{l}\text { Vol. } \\
(\mathrm{ml})\end{array}$ & $\begin{array}{l}\text { Activity } \\
\text { (units/ml) }\end{array}$ & $\begin{array}{l}\text { Protein } \\
(\mathrm{mg} / \mathrm{ml})\end{array}$ & $\begin{array}{l}\text { Spec. Act. } \\
(\text { units/mg) }\end{array}$ & $\begin{array}{l}\text { Yield } \\
(\%)\end{array}$ & $\begin{array}{l}\text { Purification } \\
(\times)\end{array}$ \\
\hline Filtered broth & 20000 & 17 & 15.4 & 1.1 & 100 & 1 \\
Isoelectric ppt & 1000 & 110 & 8.7 & 12.6 & 32 & 11 \\
DEAE-cellulose adsorbance & 4000 & 24.5 & 0.650 & 37.7 & 29 & 34 \\
Ultrafiltration & 200 & 479 & 0.742 & $661_{i}$ & 20 & 600 \\
Lipid extraction & 120 & 532 & 0.325 & $1640_{\mathrm{t}}$ & 18 & 1490 \\
Chromatography & 20 & 2360 & 0.060 & 39300 & 14 & 35700 \\
\hline
\end{tabular}




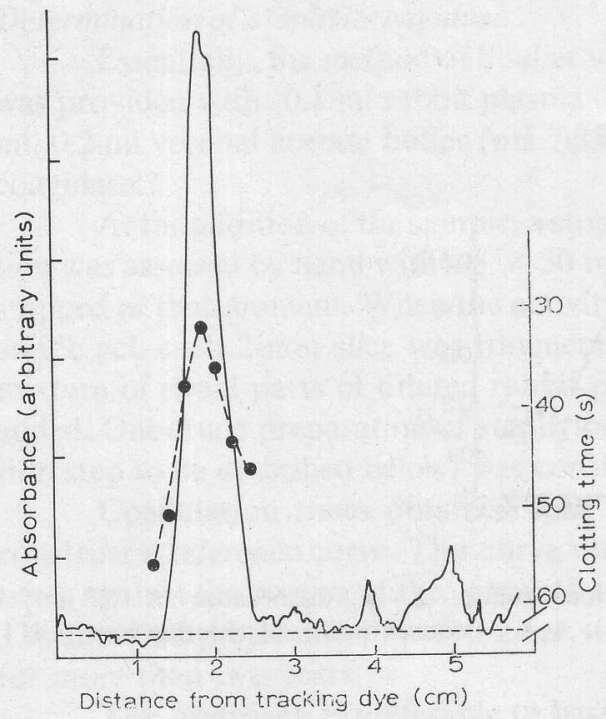

Fig. 2. Absorbance scanning of the polyacrylamide-gel electrophoresis of staphylocoagulase.

Absorbance trace; -...--, baseline; --- coagulation times obtained with fragmented 2-mm segments of an unstained gel prepared under the same conditions as the stained gel used for scanning.

coincided with the protein band. Faint contaminating bands amounting to $16 \%$ of the area under the curve and without activity were observed. Also on sodium dodecylsulphate-polyacrylamide electrophoresis of the reduced or unreduced sample only very faint contaminating bands could be observed.

\section{PROPERTIES OF STAPHYLOCOAGULASE}

\section{Molecular weight}

Gel filtration on P-100 acrylamide gel columns with the use of yeast alcohol dehydrogenase (mol. wt; 126000$)$, bovine serum albumin (mol. wt: 70000 ), ovalbumin (mol. wt: 43000 ), lactic dehydrogenase (mol. wt: 36000 ), and chymotrypsinogen (mol. wt: 25 700) as reference molecules gave a molecular weight of $62000 \pm 3000$ as the mean of ten separate estimations, calculated according to Andrews [27]. The molecular weight as estimated with the aid of sodium dodecylsulphate electrophoresis was $60000 \pm 2300$ (15 estimations); with both methods we obtained a calculated molecular weight of $61000 \pm 2300$ (see ref. 13, Fig. 5). Reduction does not change the behaviour in sodium dodecylsulphate-polyacrylamide electrophoresis.

\section{Isoelectric points}

Upon isoelectric focusing the staphylocoagulase activity eluted in a single peak in fractions with a $\mathrm{pH}$ of $4.51-4.55$.

\section{Chemical composition}

The mean amino acid composition of four different preparations is shown in Table II. The variation between the four figures for each amino acid was less than 
TABLE II

AMINO ACID COMPOSITION OF STAPHYLOCOAGULASE

The mean of four different preparations is given. The individual data differed less than $11 \%$.

\begin{tabular}{lcc}
\hline $\begin{array}{l}\text { Amino acid } \\
\text { protein }\end{array}$ & $\begin{array}{l}\text { g Amino acid/100 g } \\
\text { prine }\end{array}$ & $\begin{array}{l}\text { Nearest integer to mole } \\
\text { amino acid/mole protein }\end{array}$ \\
\hline Histidine & 9.10 & 43 \\
Arginine & 1.89 & 8 \\
Aspartic acid & 4.01 & 16 \\
Threonine & 13.18 & 70 \\
Serine & 4.74 & 29 \\
Glutamic acid & 3.71 & 26 \\
Proline & 17.58 & 83 \\
Glycine & 2.82 & 18 \\
Alanine & 3.38 & 36 \\
Cystine (half) & 5.09 & 44 \\
Valine & 1.64 & 10 \\
Methionine & 6.96 & 43 \\
Isoleucine & 1.51 & 7 \\
Leucine & 6.42 & 35 \\
Tyrosine & 7.70 & 42 \\
Phenylalanine & 3.99 & 15 \\
Tryptophan & 4.53 & 19 \\
\hline
\end{tabular}

${ }^{\star}$ Determined according to Scoffone et al. [28].

$9 \%$. Carbohydrate staining of the polyacrylamide gels of the purified product was negative. A 0.2-ml aliquot containing $100 \mu \mathrm{g}$ protein was dansylated and hydrolysed as indicated in ref. 18 . The maximal yield of dansylated N-terminal amino acid is $\approx 1.5$ nmoles. Upon polyamide-sheet chromatography, apart from the usual $\varepsilon$-Dnslysine, $\mathrm{O}$-Dns-tyrosine, Dns- $\mathrm{NH}_{2}$ and Dns-OH, only Dns-aspartic acid could be identified. This was verified by co-chromatography of Dns-aspartic acid or Dnsglutamic acid. No parasitic spots were observed. Co-chromatography of 0.1 nmole of various Dns-amino acids gave readily discernable spots. As this concentration is $<7 \%$ of the maximal yield of the $\mathrm{N}$-terminal of the main protein it was concluded that no contamirants were present in a concentration of more than $5-10 \%$ unless they had N-terminal amino acids that form labile Dns compounds (proline, tryptophan). When 3-6 times the normal amount of the hydrolysate was applied to the sheets hardly discernable parasitic spots were observed.

\section{DISCUSSION}

Staphylocoagulase is a single-chain protein with a molecular weight of 61000 \pm 2300 as determined by sodium dodecylsulphate-gel electrophoresis and gel filtration. The degree of purification obtained by our method compares favourably with that obtained by other authors as far as can be judged from their data. Siwecka and Jeljaszewicz [6] reported obtaining a 1355 -fold purification at a $1.3 \%$ yield with the method of Duthie and Haughton [2] and a 5000-fold purification at a $77 \%$ yield with the method of Zolli and San Clemente [9]. This is the highest purification we found to 
have been reported. Our method produces staphylocoagulase that routinely has a specific activity which is more than seven times higher. This may be due either to a difference in the starting material. resulting from a different strain of Staphylococcus, or to a better purification method. From the N-terminal amino acid analysis we concluded that individual contaminating proteins were present in a concentration of less than $\approx 7 \%$. In the polyacrylamide electrophoresis pattern (Fig. 2) three small accessory peaks could be seen. They contributed $16 \%$ to the total area between the curve and the baseline in Fig. 2. Comparable results were obtained in sodium dodecylsulphate-polyacrylamide electrophoresis. As the scanning tends to underestimate high density bands we estimate the amount of contaminating proteins to be $<15 \%$. We were not able to raise antibodies against our preparation. When antibodies were raised against coagulase-thrombin one precipitation line was seen between this antibody and our preparation (see ref. 13).

\section{ACKNOWLEDGEMENTS}

We wish to thank Mme O. Prou-Wartelle for help in an early phase of the work and Professor J. P. Soulier for providing the Staphylococci. We are grateful to Dr L. F. Bernini for carrying out the amino acid analysis. This investigation was financially supported by the Ministry for Public Health.

\section{REFERENCES}

1 Blobel, H., Berman, D. T. and Simon, J. (1960) J. Bacteriol. 79, 807-815

2 Duthie, E. S. and Haughton, G. (1958) Biochem. J. 70, 125-134

3 Jackerts, D. (1956) Z. Hyg. Med. Microbiol. Immunol. Virol. 142, 213-218

4 Jeljaszewicz, J. (1958) Acta Microbiol. Pol. 7, 17-34

5 Murray, M. and Ghodes, P. (1960) Biochem. Biophys. Acta 40, 518-522

6 Siwecka, M. and Jeljaszewicz, J. (1968) Zentralbl. Bakteriol., Parasit., Infektionski. Hyg. 208, 385-394

7 Soulier, J. P., Lewi, S., Panty, A. M. and Prou-Wartelle, O. (1967) Rev. Fr. Etud. Clin. Biol. 12, $544-588$

8 Tager, M. (1948) J. Biol. Med. 20, 487-501

9 Zolli, Z. and San Clemente, C. L. (1963) J. Bacteriol. 86, 527-535

10 Lowry, O. H., Rosebrough, N. J., Farr, A. L. and Randall, R. J. (1951) J. Biol. Chem. 193, 265275

11 Gornall, A. G., Bardawill, C. J. and David, M. M. (1949) J. Biol. Chem. 177, 751-766

12 Bligh, E. G. and Dyer, W. (1959) Can. J. Biochem. Physiol. 37, 911-917

13 Hemker, H. C., Bas, B. M. and Muller, A. D. (1974) Biochim. Biophys. Acta 379, 180-188

14 Chen, P. S., Toribara, T. Y. and Warner, H. (1956) Anal. Chem. 28, 1756-1758

15 Wagener, H. (1967) Lipids and Lipidoses (Schletter, G., ed.), pp. 190-210, Springer-Verlag, New York

16 Sperry, W. M. (1955) Methods of Bioehemical Analysis (Glick, D., ed.), Vol. VI, part 2, pp. 83111, Interscience Publishers, New York

17 Power, T. F. and Bennett, D. J. (1970) Anal. Biochem. 36, 537-539

18 Gray, W. R. (1967) Meth. Enzymol. 11, 139-157

19 Woods, K. R. and Wang, K. T. (1967) Biochim. Biophys. Acta 133, 369-370

20 Croft, L. R. (1972) Biochem. J. 128, 961-970

21 Weber, K. and Osborn, M. (1969) J. Biol. Chem. 244, 4406-4412

22 Whitaker, J. R. (1963) Anal. Chem. 35, 1950

23 Haglund, G. (1967) Sci. Tools 14, 17-23 
24 Bloemendal, H. and Schoenmakers, J. G. G. (1968) Sci. Tools 15, 6-7

25 Godson, G. N. (1950) Anal. Biochem. 35, 66-76

26 Frieson, A. D., Jamieson, J. I. and Ashton, F. E. (1971) Anal. Biochem. 41, 149-157

27 Andrews, P. (1964) Biochem. J. 91, 222-233

28 Scoffone, E., Fontana, A. and Rocchi, R. (1968) Biochemistry 7, 971 